\title{
OPTIMIZATION OF MEASUREMENT POINTS CHOICE IN PREPARATION OF GREEN AREAS ACOUSTIC MAP
}

\author{
Małgorzata SZTUBECKA ${ }^{1}$ Adam BUJARKIEWICZ, Jacek SZTUBECKI \\ University of Technology and Life Sciences in Bydgoszcz, Bydgoszcz, Poland
}

\begin{abstract}
The aim of the article is to analyze the selection of measuring points of sustainable sound level in the spa park. A set of points should allow to make on their basis an acoustic climate map for the park at certain times of day by usage available tools. Practical part contains a comparative analysis of developed noise maps, taking into account different variants of the distribution and number of measuring points on the selected area of the park.
\end{abstract}

Keywords: maps, acoustic maps, noise, green areas

\section{INTRODUCTION}

Maps form the basis of the information about the area. Those on selected issues are part of thematic maps. Among them we can distinguish engineering or geodetic maps, those which include socio-economic phenomena, e.g. distribution of population, administrative divisions of the country, transport network or maps of natural phenomena such as natural resources, pollution of the environment, temperature and noise patterns [10, 11]. A noise map is a graphical presentation of the acoustic data. Creating such maps for urban areas is a legal requirement. According to the act Environmental Protection Law, Article 118a:

\footnotetext{
${ }^{1}$ Corresponding authors: University of Technology and Life Sciences in Bydgoszcz, Faculty of Civil and Environmental Engineering and Architecture, Al. Prof. S. Kaliskiego 7, 85-796 Bydgoszcz, Poland, +48523749942, e-mail: sztubecka@utp.edu.pl, adamb@utp.edu.pl, jaceksz@utp.edu.pl
} 
"1. The acoustic map, developed on the copies of the maps that are part of the state surveying and cartographic resource base, is the primary source of data used for the purposes of:

1) informing the public about the noise dangers for the environment;

2) producing data for state environmental monitoring;

3) create and update programs for environmental protection against noise [15]."

Information which an acoustic map contains is primarily used to identify an existing acoustic situation for the area of concern, designate the areas where permissible noise levels are exceeded, estimate the number of inhabitants exposed to excessive noise and finally to estimate the possible actions for the protection of the environment against noise $[1,6,7]$. For the green areas such maps are not performed because there is a belief that these areas are zones of silence. The main task of these areas is to create the conditions for a peaceful individual and unorganized rest. However, in the parks of a larger area there is accumulation of different features next to each other. Next to the silence or walking zone there may occur the sports or fun zone $[4,5,13]$. On such area it is extremely difficult to separate different functions from each other. Therefore, determining acoustic climate properly may increase the attractiveness of the park, depending on its intended use.

The knowledge of the sound sources location allows to choose the proper measuring points. This has its impact on the correct development of noise maps. In environmental studies, different cartographic methods are applied to present data graphically. One of them is called isolines method, which is based on the measured values of the phenomenon in a specific geographical area $[2,14]$. The article proposes a method of searching for the optimal number of measuring points, which provides proper accuracy in developing such a map and reduces the effort put into area measurements.

\section{RESEARCH MATERIAL AND METHODS}

The area of the study is the "Solanki" brine-spa park in Inowrocław. The city is located in the south-western part of the Kuyavian-Pomeranian Voivodeship and it combines its spa town nature with the economic centre function. The spa district is located in the north-western part of the city. Spa park is arranged with a view to fit guests or patients, enabling them recreation and leisure facilities located on its terrains. Figure 1 shows the sound sources affecting the development of acoustic comfort on both the outside and inside of the park. 


\section{The SPA Park scheme - Inowroclaw}

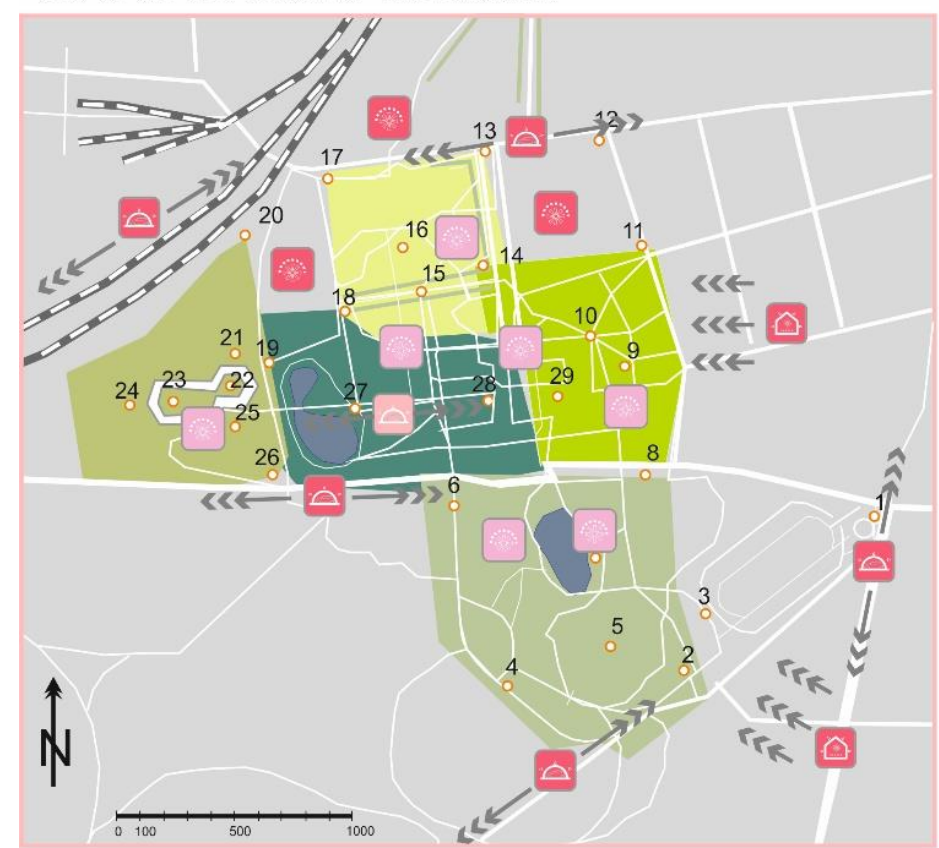

legend

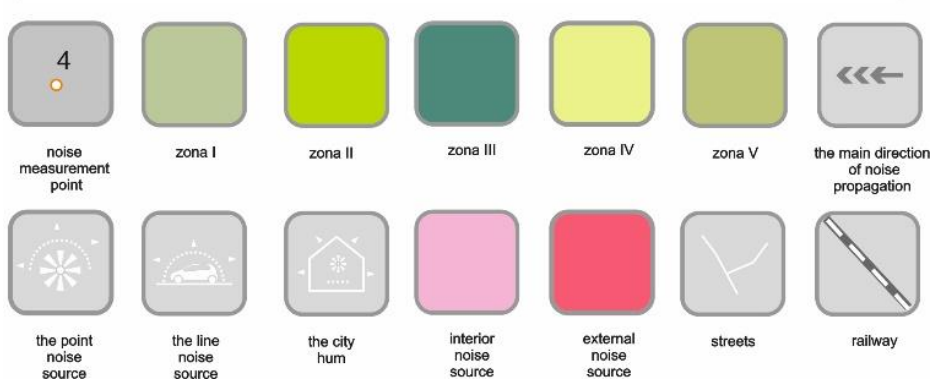

Fig. 1. Map of the park with noise sources and measurement points [13]

In order to generate the map of acoustic climate, in selected points, there were performed measurements of equivalent sound level - $\mathrm{L}_{\text {Aeq. }}$. On the basis of these measurements a map of the park acoustic climate have been developed - as shown in figure 2. This objective was achieved through the use of SoundPLAN software, which is used to create digital noise maps and it works in accordance with the requirements set out in Directive COM(2000) 468 final, Directive of the European Parliament and of the Council relating to the Assessment an Management of Environmental Noise [3]. The developed noise map allows for an identification of the areas of diverse sound levels. 


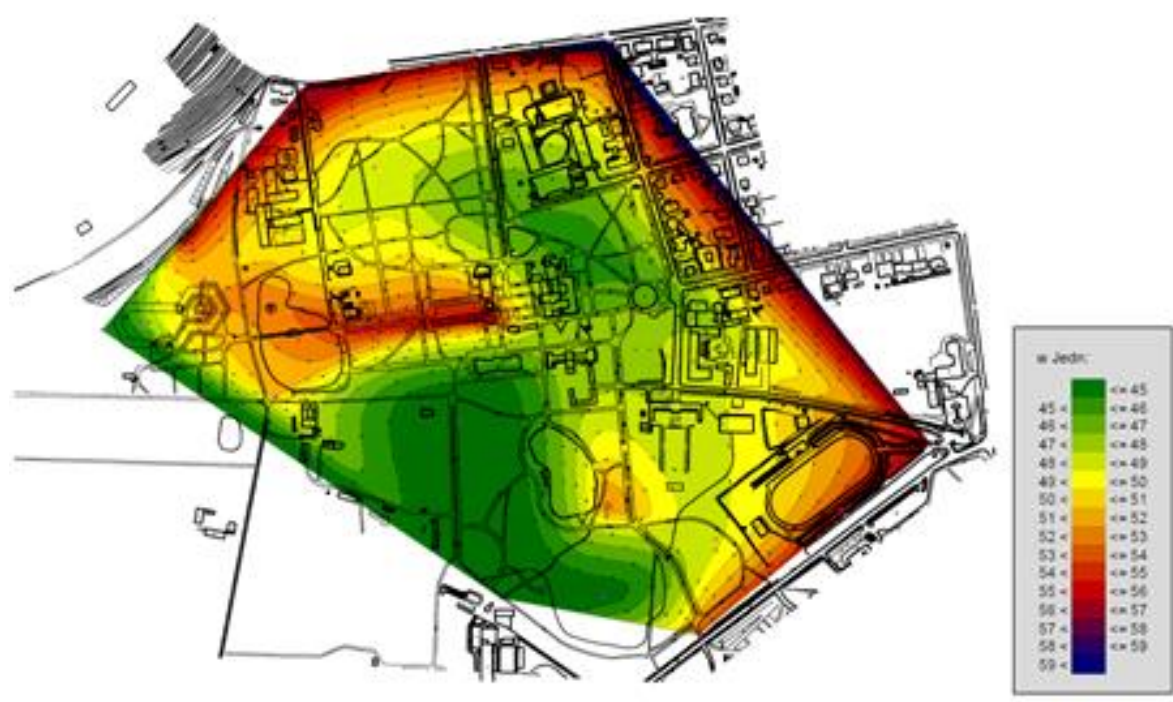

Fig. 2. The acoustic climate map of spa park "Solanki" [Lemitor Ochrona Środowiska Sp. z o. o.]

With the results including the maximum number of points, we get the map that doesn't show the sound-level values for different times of day because of the long duration of measurement.

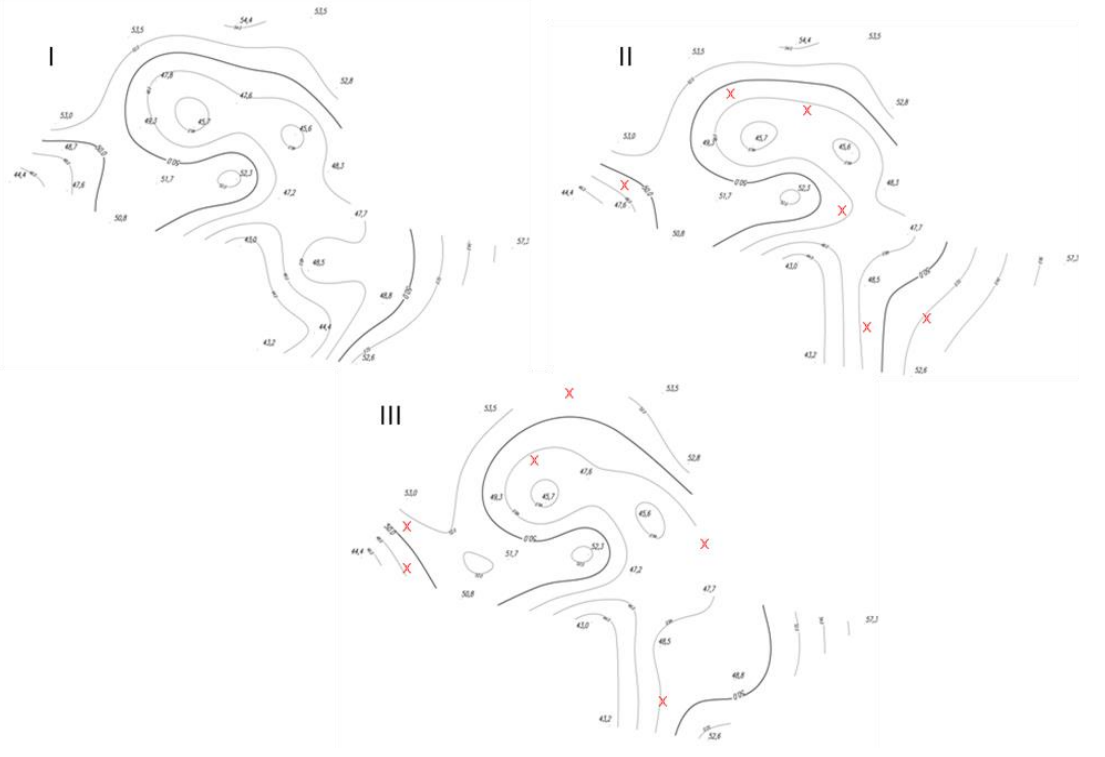

Fig. 3. Noise maps for adopted variants 
Reducing this number will enable shortening the time of measurements and taking them for a specified time of day. Because the availability of specialized software used for noise analysis is difficult, for the presentation of isolines of the sound level there was used other software which makes it possible to easily change the number of measuring points. In order to verify the assumptions there was made a linear interpolation in C-GEO for the three variants differing in arrangement and number of measuring points (fig. 3 ).

Option I, with 27 measuring points, was taken as a baseline option. In option II points within an area with similar value of equivalent sound level were removed (six points), and in option III - the four boundary points and two inside the area (six points) were also removed.

\section{RESULTS}

To be able to compare options II and III with a baseline option - I, the park area was covered with a grid of points spaced apart by 25 meters (679 points). In the grid points, for each option, there were calculated the values of the equivalent sound level. Then the differences in those points between variants I and II and I and III, as well as the average interval, have been calculated (table 1).

Table 1. Average intervals between taken options for calculation network

\begin{tabular}{|c|c|c|}
\hline & \multicolumn{2}{|c|}{ Interval between options for calculation network 25x25 m } \\
\hline & $\Delta \mathrm{dB}$ vII-vI & $\Delta \mathrm{dB}$ vIII-vI \\
\hline average interval & $0,9 \mathrm{~dB}$ & $0,7 \mathrm{~dB}$ \\
\hline Average interval & $0,9 \mathrm{~dB}$ & $0,7 \mathrm{~dB}$ \\
\hline Minimum & $-2,9 \mathrm{~dB}$ & $-1,1 \mathrm{~dB}$ \\
\hline Maximum & $4,5 \mathrm{~dB}$ & $4,2 \mathrm{~dB}$ \\
\hline
\end{tabular}

The above table shows, that option III, in which the boundary points and two points inside the park have been removed is more proper for the analyzed area. The selection of measuring points of equivalent sound level should take into account all sources of noise, both these internal and external. Sufficiently high density of points allows us to "skip" nonlinear propagation of sound. The analysis carried out as well as tools which were applied, have shown that in such studies linear interpolation can be used. While measuring the sound level, it's also important to notice the dynamics of the analyzed areas. Many authors pay attention to this $[1,8,9,12]$. The park is used differently depending on the time of a day or a year. It is appropriate to determine such number of measuring points that allow capturing the difference in use of such area. Further development made with available, simple methods will improve the process of managing such areas. 


\section{CONCLUSIONS}

The map of acoustic climate is a presentation of the distribution of sounds through the study area. It shows the zones exposed to excessive noise. Owing to it an appropriate space management for the acoustic is possible. Shaping the acoustic climate of green areas is influenced by many factors, such as:

- the size of the area,

- the accumulation of sound sources,

- the topography,

- natural or artificial obstacles,

- selection of measuring points.

Spa park in Inowrocław focuses many features associated with healthcare, entertainment, recreation and relaxation. Study of noise for this type of areas can be a primary document used in the management of the space.

Research shows that:

1. Optimizing the number of measuring points gives the ability to perform measurements during one day having regard to its different times.

2. Controlled reduction in the number of points does not significantly affect the proper defining of acoustic climate of the park.

3. Properly selected number of measuring points and their location allows use of the linear interpolation.

The results presented are the starting material for further analysis related to the use of, for example, a different interpolation method and taking into account natural and artificial obstacles affecting sound propagation on such area.

\section{REFERENCES}

1. Aletta F., Kang J.: Soundscape approach integrating noise mapping techniques: a case study in Brighton, UK, Noise Mapping 2, 2015, 1-12.

2. Bac-Bronowicz J., Methods of the visualisation of precipitation based on various observation measurement periods in GIS. Acta Univ. Wratisl., 2542, Stud. Geogr., 75, 2003, 559-563.

3. $\operatorname{COM}(2000) 468$ final, Directive of the European Parliament and of the Council relating to the Assessment an Management of Environmental Noise.

4. Dąbkowski N., Pędzich B.: The problem of adapting existing residential buildings in the country to the requirements of ecology, Civil and Environmental Engineering Reports, 2015; 18 (3): 15-21.

5. Fagiewicz K.: Post-mining landscape ecology - analysis of selected problems, the case of Adamów brown coal basin, Civil and Environmental Engineering Reports, 2013; 11: 55-66. 
6. Kaźmierczak J., Lipowczan A., Batko W., Rudno-Rudzińska B., RudnoRudziński K.: GIS-class systems of spatial information as the base for creating strategic acoustic maps of urban areas, Archives of Acoustics 31, 4 (Supplement), 2006, 261-274.

7. Kirpluk M.: Acoustic basic, Warszawa, 2016, http://www.ntlmk. com/biblioteka/M.Kirpluk\%20\%20Podstawy\%20akustyki\%20-\%20201602.pdf, (in polish).

8. Kirrian Fiedler P. E., Trombetta Zannin P. H.: Evaluation of noise pollution in urban traffic hubs - Noise maps and measurements, Environmental Impact Assessment Review 51, 2015, 1-9.

9. Kubiak J., Ławniczak R.: The propagation of noise in a built-up area (on the example of a housing estate in Poznań), Journal of Maps, 2016, Vol. 12 , Iss. 2, http://dx.doi.org/10.1080/17445647.2014.1001801.

10. Mrówczyńska M.: Selected models for the description of the kinematics of changes of height differences between points in a geodesic network under the influence of mining, Civil and Environmental Engineering Reports, No. 8, 2012, 5-17.

11. Silva, C., Silva, J., Chagas, C., Castro C.: The Cartography and the Spatial Representations: Search by Perfect Map, Journal of Geographic Information System, 6, 2014, 624-635.

12. Osmólska A., Łazarz B., Czech P.: Application of acoustic maps in the analysis of acoustic screens efficiency on the section of national road no.94 in Dąbrowa Górnicza, Zeszyty Naukowe Politechniki Śląskiej, Seria: TRANSPORT z. 73, Nr kol. 1861, 2011, 81-86 (in polish).

13. Sztubecka M., Skiba M. A.: Acoustic conditions in determined zones of homogenous development of the spa park in Inowroctaw, Zeszyty Naukowe Uniwersytetu Zielonogórskiego, 161, IŚ 41, 2016, 5-17 (in polish).

14. Sztubecki J., Sztubecka M., Bujarkiewicz A.: The usage of Geographic Information Systems in management of green areas, Ekologia i Technika, 134, 2015, 13-18 (in polish).

15. The act from 27th of April 2001 Environmental Protection Law (Dz.U. 2001 $\mathrm{Nr} 62$ poz. 627 with changes) (in polish).

\section{OPTYMALIZACJA WYBORU PUNKTÓW POMIAROWYCH W OPRACOWANIU MAP AKUSTYCZNYCH TERENÓW ZIELONYCH}

\section{Streszczenie}

Celem artykułu jest analiza wyboru liczby punktów pomiarowych równoważnego poziomu dźwięk na terenie parku zdrojowego. Zbiór punktów powinien zapewniać 
wykonanie na ich podstawie mapy klimatu akustycznego parku dla określonych pór dnia, przy wykorzystaniu powszechnie dostępnych narzędzi. Część praktyczna zawiera analizę porównawczą opracowanych map hałasu, uwzględniającą różne warianty rozmieszczenia i liczby punktów pomiarowych na wybranym obszarze parku.

Słowa kluczowe: mapa, mapa akustyczna, hałas, tereny zielone

Editor received the manuscript: 13.10 .2016 